\title{
Duch, Lluís y Chillón, Albert (2012): Un ser de mediaciones: antropología de la comunicación. Vol I. Barcelona: Herder, 512 pp. ISBN: 978-84-254-3074-9
}

En una conocida parábola de Toni Morrison, la autora da vida al lenguaje, tratándolo como una "cosa viviente", perspectiva que no es falsa ni irreal, sino que indica un aspecto verdadero del lenguaje. En esta parábola, unos niños inician un juego cruel preguntando a una mujer ciega si el pájaro que ellos guardan en sus manos está vivo o muerto. La mujer ciega responde negando y desplazando la pregunta: "No sé (...) lo que sé es que está en tus manos. Está en tus manos"1. El lenguaje es una cosa viviente, que cobra vida desde el silencio mismo del habla egocéntrica del niño ${ }^{2}$. En la correspondencia de personajes, Morrison decide interpretar la mujer de la parábola como una escritora experimentada, y el pájaro, como el lenguaje, intentando hacer una conjetura acerca de cómo esta escritora imagina el lenguaje: "Ella piensa el lenguaje en parte como un sistema, y en parte como un ser vivo sobre el que uno tiene control, pero sobre todo como agencia -el objeto de la formulación más su misma acción-. Por tanto la pregunta que le hacen los niños, ¿está vivo o muerto?, no es irreal, puesto que la escritora piensa el lenguaje como algo susceptible de morir, de ser borrado" ${ }^{11}$ Y es justo ese imaginar el lenguaje como vida, el eje temático del libro de LLuís Duch y Albert Chillón Un ser de mediaciones. Antropología de la Comunicación. Desde una nítida óptica antropológica Lluís Duch y Albert Chillón, desenredan los múltiples prismas del lenguaje, desde un principio ineludible: para el anthropos no hay posibilidad extracultural, ni posibilidad de ser fuera del lenguaje. El anthropos precisa mediaciones de forma imperiosa, ya que su condición conlleva una insuperable distancia respecto de sí, del mundo y de los demás. Distancia desde la que se nutre la precariedad en que vivimos los sujetos, y que puede ser diluida desde la semiosis, el lenguaje y el símbolo, compartiendo todos ellos ser indiscernibles de la humanidad. "Toda comunicación teje nexos entre los sujetos implicados, entre la precariedad en que viven y su posible superación" (p. 24).

Tal y como se dice en el Preámbulo de esta obra, "son varios y hasta opuestos, los tipos de antropología que hoy se cultivan, rasgo congruente con las premisas mismas de su mirada". El discurso de Duch y Chillón, no solamente capea todas las antropologías posibles, sino también toda nuestra decisiva y repetitiva

\footnotetext{
Morrison, T. (1994): The Nobel Lecture in Literature. New York: Knopf.

2 Vygotsky, L. (1995): Pensamiento y lenguaje. Barcelona: Paidós.
}

performatividad corpórea, junto al actual escenario mediático. "El anthropos u Homo es sapiente (sapiens) y hablante (loquens), religioso (religiosus), cultural y mítico (mythicus), hedonista (ludens) y riente (ridens), técnico (faber) y semiótico (signans). En algún momento y lugar, in illo tempore, el antropoide pensante se emancipa en parte de la madre naturaleza y de su armonía con el cosmos y el bios, alza la vista al frente según yergue su espina dorsal, y se distingue como sujeto de los objetos en torno y del todo en que existe. Pierde para siempre su inmediatez $y$, al romper a hablar y entrar en la historia, ingresa en el reino de lo mediado sin posible vuelta atrás, enredado en las mediaciones que componen su mundo. Un mundo al que empieza a dar formar, y a informar de él, a través del lenguaje simbólico y en que tras dar luz al símbolo, se cubre de un sentido logomítico. La dialéctica entre mythos y logos, que integra razón y emoción, concepto y sentimiento, análisis y síntesis, silogismo y argumento, puesto que ambos se hallan coimplicados. "Los grandes mitos -y las incontables narraciones que de ellos derivan -son "afectivos", más que rudamente efectivos, y exploran la "experiencia", en vez del expermentum, a diferencia del logos científico. Si el ser humano es un "animal logomítico", si en él conviven problemáticamente logos y mythos $-\mathrm{y}$ no uno u otro, como suele pensarse-, el mito y la narración expresan la constante urgencia de comprender su existencia" ( $p$. 41).

Siguiendo con la obra Un ser de mediaciones, varios de sus capítulos reconstruyen esa capacidad representativa del lenguaje, en concreto al hablar de la imaginación creadora, de la narración interminable (ideas sobre la figuración del espacio narrativo y la ideación de los personajes) y del tenor lingüístico de la experiencia. En realidad ambos autores hacen una auténtica fisiología de la función de las estructuras antropológicas del imaginario que alcanzan un protagonismo en la constitución del mundus histórico, esto es, por los imaginarios que a un tiempo inspiran y expresan el efectivo existir de grupos y sujetos. Pero antes de llegar a la antropología del imaginario, se hace un reconocimiento obligado al estatuto fundante de la imaginación primera. Tal y como dice Hegel (rescatando los postulados de Aristóteles), la imaginación no es un simple "término medio", sino el "primero y originario". La imaginación creadora trasciende la dicotomía idea o concepto y sensación. Se trata de algo interior lejano de la división misma entre lo falso y lo verdadero, ya que es facultad psíquica radicalmente generatriz, creadora y "presentativa". Y "ese es el escándalo de la imaginación al que alude con razón Castoriadis" (p. 249), es un 
esclarecer el dinamismo de la "imaginación primera" . A su vez esa función generatriz de la imaginación se consolida desde los aportes de Kant, para quien la imaginación es la "forma pura mediante la cual tiene forzosamente que representarse a priori todo objeto de experiencia"(p. 251)

De igual relevancia, es el capítulo dedicado a la narración interminable, y más si tomásemos por inevitable y certera la extinción del arte de narrar, tal y como pronostica W. Benjamín, "se aproxima a su fin, porque el aspecto épico de la verdad, es decir, la sabiduría, se está extinguiendo" ${ }^{3}$, al igual que en la parábola de Morrison, la narración es susceptible de morir, de ser borrada. El paisaje comunicativo que nos ofrecen los autores es esperanzador pues para ellos, la presente cultura mediática, acusadamente tecnológica e industrial, así como su ciberentorno están promoviendo un sensorium distinto, en el cual -a pesar de la férula que ejerce la información- resta un minoritario aunque sensible margen para que medren la comunicación y la narración genuinas. Desde este nuevo sensorium cibermediático se promueven situaciones, actitudes y efectos en una doble vía: una información abstractiva, impersonal y presentista que debilita la narración, frente a nuevos vínculos y nuevas sensibilidades alejadas de la "cultura de masas". Quizás un buen antídoto ante esa probabilidad -el fin del arte de narrar-, sea una nueva aprehensión a la memoria colectiva, poseedora de una función terapéutica, cultural y socializadora. Roger Bastide también ha insistido en la capacidad de la memoria colectiva para innovar, resituar la afectividad, activar lo ausente y en especial para instituir recuerdos que espolean creatividades, utopías y deseos (p. 411).
Otro buen antídoto lo constituye sin duda alguna esta brillante obra Un ser de mediaciones, que desde la reflexión antropológica, y en los extensos lindes de las ciencias sociales y humanas, nos descubren en el actual ciberentorno una memoria colectiva que sigue ejecutando en, con y por medio de la dialéctica comunicativa de las comediaciones su carácter de memoria proyectiva. Como tal, no está encorsetada dentro de unos límites culturales y unos límites de sentidos ya existentes en el imaginario social. Esto último marcaría un ritmo determinista de reproducción social, es decir, no podremos ser jamás más que algo parecido, común de lo que hemos sido y somos, una sucesión de continums. Por el contrario "lo que seré", "lo que seremos" está sujeto a unas leyes socioculturales, a la teoría del caos social, pero abocado irremediablemente a un caos creativo, a una especie de improvisación cultural, íntimamente ligada y conectada a la soberanía de la palabra, que está en las manos de todo ser de mediaciones. "Lo sé (...) lo que sé es que está en tus manos. Está en tus manos".

Carmen Gaona Pisonero Universidad Rey Juan Carlos, España carmen.gaona@urjc.es

Recibida: 3-4-2014 Aceptada: 5-5-2014

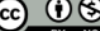

\footnotetext{
${ }^{3}$ Benjamin, W. (1998): Para una crítica de la violencia y otro ensayos, Iluminaciones IV: 119-351. Madrid: Taurus.
} 